\title{
Central Nervous System Paracoccidioidomycosis: An Overview
}

Sérgio Monteiro de Almeida
Neurology Division, Federal University of Paraná; Curitiba, PR, Brazil

\begin{abstract}
Paracoccidioidomycosis (PCM) is an infectious disease, endemic to subtropical areas of Central and South America, caused by the dimorphic fungus Paracoccidioides brasiliensis. It is a chronic disease, mostly affecting adult males, with a mean patient age of 44 years. Central nervous system involvement (CNS PCM) has been found in $13 \%$ of the patients with systemic disease. We reviewed the clinical presentation, diagnosis techniques and treatments for CNS PCM. .

Key Words: Paracoccidioidomycosis, neuroparacoccidioidomycosis, central nervous system, cerebrospinal fluid, Paracoccidioides brasiliensis.
\end{abstract}

\section{Etiologic agent}

Paracoccidioidomycosis (PCM) is a chronic granulomatous infectious disease. The etiologic agent is the thermally dimorphic fungus Paracoccidioides brasiliensis (Splendore, 1912) [1]. At $19^{\circ}-28^{\circ} \mathrm{C}$ the fungus develops as a mold and produces slowgrowing colonies; the microscopic structures are thin septet hyphae with chlamydospores, which is the form found in nature. Chlamydospores are the infectious form of the fungus. In cultures at $37^{\circ} \mathrm{C}$, as well as in tissues and exudates, the fungus appears as an oval-to-round yeast cell that reproduces by multiple budding; the "pilot wheel" cell is characteristic [2].

\section{PCM geographic distribution}

PCM is the most prevalent systemic mycosis in many countries in Latin America. Its distribution is limited to subtropical regions of Central and South America,

Received on 18 November 2004; revised 24 March 2005.

Address for correspondence: Dr. Sérgio Monteiro de Almeida, MD, PhD. Hospital de Clínicas - UFPR, Especialidade de Neurologia. Rua General Carneiro, 181, sala 1236,Zip code: 80060900 Curitiba - PR-Brazil.E-mail: sdealmeida@ popmail.ucsd.edu. Phone/fax 55(41) 264-3606.

The Brazilian Journal of Infectious Diseases 2005;9(2):126-133 (C) 2005 by The Brazilian Journal of Infectious Diseases and Contexto Publishing. All rights reserved. where it is endemic. Approximately 10 million people are infected by this fungus and up to $2 \%$ of them may develop the disseminated forms of the disease [3]. It has been reported only in Latin America, from Mexico (20 degrees N) to Argentina (35 degrees S). However, some countries within these latitudes are not affected (some of the Caribbean Islands and Chile). The characteristics of endemic regions are mild temperature and relatively high and constant humidity throughout the year [4]. In these regions, P. brasiliensis exists both as a plant and soil saprophyte [1,5-7]. Naturally acquired animal infection has been demonstrated only in armadillos (Dasiypus novemcinctus) [4,7].

Nonautochthonous cases have been reported outside the endemic area. All of these patients have either lived in or visited Latin America at least once. Therefore, PCM can be considered a traveler's disease $[1,8]$. This disease has long periods of latency; some nonautochthonous infections develop over 30 or more years after leaving the endemic regions [2].

The constant movement of people from rural to urban areas and an increase in the average life span will certainly contribute to a higher frequency of patients with immunosuppressive diseases [9-14] or conditions for endogenous reinfection of a quiescent PCM focus $[1,15]$. The association of systemic PCM with pulmonary $\mathrm{Tb}$ is common, but there have been no reports of association of $\mathrm{Tb}$ meningitis with PCM in the Central Nervous System (CNS PCM). 


\section{Pathogenesis}

Nowadays, inhalation is considered the most important route of infection. After inhalation, the chlamydospores, which are the infecting particles, transform to the yeast form in the patient's body. The primary site of infection, which is often not apparent, is the lungs. After being inhaled, P. brasiliensis causes a benign and transient pulmonary or oral infection in normal individuals. The primary infection is almost always subclinical in individuals with a normal immune system. If the host becomes immune depressed, a later subsequent reactivation results in chronic infection of the lungs or other organs, especially mucous and cutaneous tissue, lymph nodes, adrenals and the central nervous system (CNS) [5,6]. PCM is not contagious from person to person, because at body temperature the fungus is in the yeast form.

\section{The involvement of the CNS}

Central nervous system (CNS) involvement of paracoccidioidomycosis(neuroparacoccidioidomycosis, NPCM) occurs more frequently than has been admitted in the past $[1,16]$. NPCM should always be considered in the differential diagnosis of meningoencephalitis and in expansive processes of the $\mathrm{CNS}$, especially in endemic areas or among individuals who have visited these regions [1].

Whenever the CNS is involved, most patients have a widely disseminated disease that is easily identified. NPCM may occur without any other manifestation of the disease. There may be histopathological evidence of NPCM in patients with no clinical symptoms.

The frequency of CNS involvement in PCM is extremely variable, from $9.65 \%$ to $25.45 \%$ [1,15-19]. There have been an increasing number of reports of NPCM, most of which involve neurosurgical or anatomopathological findings [1,16,17,19-26].

Classically, PCM is a disease of young males (mean age 44 years) and rural workers [16]. It predominates in male patients at a rate of 9-15/1 [2]; NPCM seems to be even more rare in woman, with a male/female ratio of 23/1 [16]. It has been suggested that the sex difference could be explained by the inhibitory action of estrogens on the transformation of conidia or mycelium to the yeast form $[1,2,27]$. When the disease occurs in prepubertal patients, there is no gender difference; the same is true for postmenopausal patients. Also, the PCM skin test in endemic areas is equally positive for both sexes, showing no difference in exposure or infection [2].

The involvement of the CNS in PCM (NPCM) is secondary to a primary focus. The fungus disseminates from a primary focus, through the hematological and/ or lymphatic route, and possibly also by contiguity. Simultaneous involvement of other organs or systems does not necessarily occur. CNS involvement is not necessarily accompanied by dissemination of the disease, and in some cases it is the preferential or the only location of the disease [28].

In $21 \%$ of the cases the onset of neurological symptoms was found to take place before the onset of systemic symptoms; in 33\% they happened simultaneously and in $46 \%$ they appeared after the onset of the systemic symptoms [16].

\section{Clinical features}

The granulomatous form predominates in the CNS in $96 \%$ of cases, mainly in the brain hemispheres, although it can occur in any location of the CNS [16]. Clinical manifestations are not specific and depend on the CNS location of the lesion [1520,23,25,26,29-31]. The most frequent clinical manifestations are seizure in $33 \%$, hemiparesis in $25 \%$, cerebellar signs in $25 \%$, headache in $21 \%$, and hydrocephalus in $21 \%$; less frequent symptoms include paresthesias in 13\%, confusion in 13\%, and bulbar signs in $8 \%$ [16]. Some cases can have an initial diagnosis of brain tumor [31].

A published case presented with Holmes tremor, a resting and intention tremor with sometimes irregular presentation. Postural tremor is also be found in many patients. The tremor is not as rhythmic as are other tremors; it has a slow frequency, usually less than $4.5 \mathrm{~Hz}$, and a typical delay between the time when the lesion occurs and the onset of the tremor is two weeks [29]. 
Meningitis associated with granuloma can occur in $17 \%$ of NPCM cases [16]. Although meningitis alone brought on by $P$. brasiliensis is rare, the patient can present with meningeal signs. It is a skull base meningitis, characterized by a mild to moderate increase in cerebral spinal fluid (CSF) cell count, predominated by monocytes and lymphocytes; in some unusual cases the CSF cell count is higher than 700 cells $/ \mathrm{mm}^{3}$ [32].

NPCM in the spinal cord is rare; it accounts for $0.6 \%$ of all cases of systemic PCM and $4 \%$ of NPCM cases. The first report of NPCM in the spinal cord was published by Canelas et al. in 1951. Since then, there have been 13 published cases, all of them from Brazil [13,16,21,22,24,26,33-37]. The most frequently involved spinal cord levels are thoracic (58\%), cervical $(25 \%)$, and both (8\%). Clinical features suggest spinal cord compression, transverse myelitis, and signs of spinal root compression or conus medullaris involvement, with arachnoiditis [33,21].

\section{Diagnosis}

The diagnosis of systemic PCM is not difficult; it is established by visualization of $P$. brasiliensis upon light microscopic examination, isolation of the fungus by culture from biological specimens (sputum or biopsy samples) and by immunological tests of serum, such as double immunodiffusion (DID) or ELISA with specific antigens $[38,39]$. On the other hand, the diagnosis of NPCM is often difficult, and a strong clinical suspicion is necessary. This frequently occurs when a patient from an endemic area or with a history of traveling to an endemic region, or a patient who has systemic PCM, has neurological signs or symptoms $[1,16]$.

Adefinitive diagnosis is usually made by visualization or isolation of the fungus $P$. brasiliensis from CNS biopsy or necropsy material. However, finding the fungus in the CSF, is time consuming, is not efficient, and rarely occurs $[16,40]$. Biopsy of brain lesions is a definitive but invasive procedure, and not infrequently the lesions are located in regions where a biopsy cannot be safely performed.

\section{Cerebrospinal fluid}

There are few studies involving CSF in NPCM patients [16,41]; this subject should be better studied in NPCM. The CSF has a poor diagnostic value because biochemical or cytological alterations are noncharacteristic and CSF mycological examinations (microscopic examination and cultures) are usually negative, even in cases of meningitis.

The main CSF alterations are an increase in total protein (TP) and gammaglobulin. Among 18 cases, an increase of CSF TP was found in $61 \%$; the mean total CSF protein level was $62.7 \pm 42.6 \mathrm{mg} / \mathrm{dL}$ (ranging from 21 to $181 \mathrm{mg} / \mathrm{dL}$ ). This increase could be related to blood brain barrier (BBB) disruption or intrathecal production of antibodies. Gammaglobulin was determined by electrophoresis in 11 patients, with the average being $15.5 \pm 6.1 \%$ (ranging from 7.8 to $26.5 \%$ ). It was present at higher than normal levels in seven cases $(63 \%)$. When the relationship between CSF TP and gammaglobulin [42] was examined, most cases had a normal relationship, $25 \%$ of the cases had a BBB disruption, and $25 \%$ had $\mathrm{BBB}$ disruption and intrathecal synthesis $[16,41]$. Although this is a very inexact manner to study the $\mathrm{BBB}$, it can give a preliminary overview of $\mathrm{BBB}$ function in this disease; more studies on this subject should be made.

An increase of CSF cells was found in $17 \%$ of the cases. The mean number of cells was $2.6 \pm 4.2$ cells/ $\mathrm{mm}^{3}$ (ranging from 0.3 to 14). Glucose was normal in all cases; mean glucose was $65.2 \pm 9.4 \mathrm{mg} / \mathrm{dL}$ (ranging from 51 to $85 \mathrm{mg} / \mathrm{dL}$ ) [16].

Direct microscopic examination for fungus and culture for $P$. brasiliensis were negative in all samples, including those cases with an increased cell number. DID was also negative in all CSF samples [16,41]. As the diagnosis of NPCM is difficult, and there is no specific CSF or radiological characteristic, it is important to look for specific tests of the CSF, using immunological reactions or molecular biology [43].

A $43 \mathrm{kDa}$ glycoprotein, gp-43, is found in $P$. brasiliensis. It is the most important antigen of this bacterium [45-49]. It is secreted exocellularly during 
the infective yeast phase and is the main PCM diagnostic antigen, being recognized by virtually all sera from PCM patients in various test formats [50]. A strong antibody response against gp43 is observed in PCM patients, and specific antibodies persist for a long time [44].

The importance of the search for these antibodies is corroborated by the fact that $63 \%$ of the CSF samples had an increase in gammaglobulin synthesis, which could indicate intrathecal antibodies. This increase has been found in the sera and other biological fluids of patients with chronic and acute forms of PCM. The $43 \mathrm{kDa}$ antigen has been detected in the serum and urine of patients with PCM [40,50-52]. ELISA anti-gp43 is positive in $89 \%$ of CSF samples from these patients, with a high sensitivity $(89 \%)$ and a satisfactory specificity (100\%). Specificity must be better studied, especially in CSF samples with other fungus diseases involving CSF. Several researchers have observed that gp43 cross-reacts with serum from patients with histoplasmosis and aspergillosis [53,54], and both these fungal infections can be found in the CNS, though they are not very common. ELISA anti-gp43 of the CSF also has high predictive values (positive $100 \%$, negative $94 \%$ ); the Youden index is 0.89 .

Detection of specific antibodies in CSF could be helpful in the diagnosis as well as for monitoring the evolution of the disease and its response to treatment. The detection of circulating gp43 antigen in CSF has a sensitivity of $100 \%$; the mean antigen concentration was found to be $19.26 \mu \mathrm{g} / \mathrm{mL}$. Serum levels were $4.59 \mu \mathrm{g} /$ $\mathrm{mL}$ lower than those obtained in CSF samples [43].

\section{Neuroimaging}

Neuroradiological methods (brain CT or MRI) are useful for diagnosis, but are not specific; the features of this disease are similar to those of all granulomatous diseases of the CNS [55-57]. CT scan images are usually hypodense, with annular or nodular enhancing, surrounded by mild edema, after contrast injection. In $65 \%$ of the patients, there were multiple mass lesions, and $35 \%$ had a single mass lesion. The granuloma was most frequently located in brain hemispheres (67\%); in $25 \%$ the location was the cerebellum and in $25 \%$ of cases it was the brainstem, while in $4 \%$ it was in the spinal cord $[16,58]$.

\section{Treatment and evolution}

Both meningitis and the parenchymatous form of NPCM are treated with antifungal drugs. The trimethoprim-sulphamethoxazole association can be used as the first therapeutic option. Sulfas are considered the drugs of choice for the treatment of NPCM, with amphotericin $\mathrm{B}$ being used only in cases with resistance or intolerance to sulfonamides. The association of sulfamethoxazole-trimethoprin is used because of the facility of its administration and low toxicity. We have previously reported 24 cases of NPCM, all treated with sulfamethoxazole-trimethoprin, using an oral dose of 160/ $800 \mathrm{mg}$ three times daily (a total daily dose of $2,400 \mathrm{mg}$ of sulfamethoxazole and $480 \mathrm{mg}$ of trimethoprin). Four patients died, while 20 patients had a good therapeutic response. After treatment, 22 cases had a brain CT scan for treatment control,; among these 14 (64\%) presented residual lesions after treatment, characterized in the CT scan as hyperdense lesions, with irregular contrast enhancement. Some cases showed residual calcified lesions. A normal brain CT scan after treatment was found in $8(36 \%)$ cases [16].

The duration of treatment depends on the clinical response [1]. Ketoconazole, itraconazole, and fluconazole have been used in the treatment of systemic PCM. The first two, particularly ketoconazole, penetrate the BBB poorly and are therefore not indicated for the treatment of NPCM. There are some reports of NPCM cases that have been successfully treated with itraconazole [59]. Fluconazole could be an alternative for treatment because it has excellent penetration into the CNS.

Voriconazole is a new wide-spectrum triazole antifungal agent, presenting both as oral and intravenous formulations. It produces in vitro activity against yeast cells of $P$. brasiliensis. This drug has potential for use in NPCM, because of its good BBB penetration [60]. Despite clinical improvement, some patients present residual lesions in the brain CT scan [1], independent of the drug used for treatment. 
Neurosurgical procedures are indicated under specific circumstances: patients with granulomas that do not respond to clinical treatment, intracranial hypertension related to hydrocephalus, or a granuloma inducing signs and symptoms of compression [1].

Due to the small number of cases reported, it is not clear whether intramedullary PCM granulomata should be surgically treated or if they are best treated with specific therapy. Some doctors consider surgical resection of the lesion when there is progressive spinal cord compression [21].

\section{PCM and HIV}

Patients with PCM and AIDS generally present a form similar to that of the more severe acute form of PCM, however this infection probably results from reactivated latent foci that lead to the less severe chronic form in nonimmunocompromised hosts $[2,11,14]$. PCM is seen as an opportunistic infection in patients with AIDS in endemic regions, but a greater increase in prevalence was expected [9-12,14,61]. It is possible to use trimethoprim-sulfamethoxazole as a prophylaxis for Pneumocystis carinii pneumonia; it is also effective against $P$. brasiliensis, which explains in part the scarcity of reported cases of systemic and NPCM [10].

\section{NPCM and HLA}

Not all individuals from endemic areas develop the disease, and there are patients with generalized systemic PCM without CNS involvement. This observation leads us to believe that conditions peculiar to each patient, probably of an immunological nature, favor the involvement of the CNS in the mycosis [62].

Some studies of association between systemic PCM and HLA were conducted on various populations (Table 1). Some of them found a positive association with HLA antigens, while in others there was no association. A positive association was found with the HLA antigens: A9, B13, B22, and B40 [63-66]; a possible negative association was found with $\mathrm{A} 1$ and B40 [63], and some studies found no association [62,
Rebelatto unpublished data, 67]. Studies of association between PCM and HLA have been made with systemic patients, and involvement of the CNS is an exclusion criterium. So there is no data about HLA and NPCM, which could be important to help understand why only some patients with systemic PCM show CNS involvement.

We reported the phenotype characteristics of six patients with NPCM [62]. In this study the HLA antigen frequency found in patients with NPCM was not different from the allele frequencies observed in the general population of Paraná state, where the white individuals are predominantly of European origin [68]. However, the number of patients in this study is not sufficient to allow conclusions to be drawn about the influence of HLA antigens in NPCM; more of these determinations could help in the study of the neuropathogenesis of NPCM.

We need to answer the questions: Why don't all people from endemic areas develop the disease? Why are there patients with generalized PCM without CNS involvement? Other individual factors, or even specific characteristics related to the fungus, such as a higher virulence or a specific CNS tropism of strains of $P$. brasiliensis could explain these unknowns, but no studies about these factors exist at the moment.

\section{References}

1. Franco M., Lacaz C.S., Restrepo-Moreno A., Del Negro G. Paracoccidioidomycosis. CRC Press, Boca Raton, 1994.

2. Restrepo A.M. Paracoccidioides brasiliensis. In: Mandel G.L., Bennett J.E., Dolin R., eds. Principles and practice of infectious diseases. 4th ed. Churchill Livingstone, New York, 1995.

3. McEwen J.G., Garcia A.M., Ortiz B.L., et al. In search of the natural habitat of Paracoccidioides brasiliensis. Archives of Medical Research 1995; 26:305-6.

4. Restrepo A. The ecology of Paracoccidioides brasiliensis: a puzzle still unsolved, Sabouraudia: Journal of Medical and Veterinary Mycology 1985;23:323-34.

5. Brummer E., Castaneda E., Restrepo A. Paracoccidioidomycosis: an update. Clinical Microbiology Reviews 1993;6:89-117. 
Table 1. Systemic paracoccidioidomycosis and associated HLA antigens

\begin{tabular}{lllc}
\hline Reference & N & Association & HLA antigens \\
\hline Restrepo et al. 1983 & 41 & Positive & A9; B13 \\
& & Negative (?) & A1; B40 \\
González et al. 1985 & 29 & Positive & B22 \\
Lacerda et al. 1988 & 83 & Positive & B40 \\
Goldani et al. 1991 & 80 & Positive & B40 \\
Ponsirenas, 1991 & 39 & No association & \\
Visentainer et al. 1993 & 40 & No association & \\
Rebelatto, 1996 & 58 & No association & \\
\hline
\end{tabular}

6. Colombo A.L., Queiroz-Telles F., Graybill J.R. Paracoccidioidomycosis. In: Mandell G.L. \& Diamond R.D. eds. Atlas of infectious diseases: fungal infection. Current Medicine, Philadelphia, 2000.

7. Restrepo A., McEwen J.G., Castaneda E. The habitat of Paracoccidioides brasiliensis: how far from solving the riddle? Medical Mycology 2001;39:233-41.

8. Fujio J., Nishimura K., Miyaji M. Epidemiological survey of the imported mycoses in Japan. Nippon Ishinkin Gakkai Zasshi 1999;40:103-109.

9. Finamor L.P., Muccioli C., Martins M.C., et al. Ocular and Central Nervous System Paracoccidioidomycosis in a pregnant woman with acquired immunodeficiency syndrome. American Journal of Ophthalmology 2002;134:456-9.

10. Goldani L.Z., Sugar A.M. Paracoccidioidomycosis and AIDS: an overview. Clinical Infecious Diseases 1995;21:1275-81.

11. Benard G, Duarte AJS. Paracoccidioidomycosis: a model for evaluation of the effects of Human Immunodeficiency Virus infection on the natural history of endemic tropical diseases. Clinical Infectious Diseases 2000; 31: 1032-1039.

12. Nobre V., Braga E., Rayes A.,et al. Opportunistic infections in patients with AIDS admitted to an university hospital of the southeast of Brazil. Revista do Instituto de Medicina Tropical de São Paulo 2003;45: 69-74.

13. Pedro R.J., Branchini M.L.M., Lucca R.S., et al. Paracoccidioidomicose do Sistema nervoso central: a propósito de dois casos. Revista do Instituto de Medicina Tropical de São Paulo 1980;22:269-74.

14. Gomez B.L., Figueroa J.I., Hamilton A.J., et al. Antigenemia in patients with Paracoccidioidomycosis: detection of the 87-kilodalton determinant during and after antifungal therapy. Journal of Clinical Microbiology 1998;36:3309-16.
15. Plá M.P., Hartung C., Mendoza P., et al. Neuroparacoccidioidomycosis: case reports and review. Mycopathologia 1994;127:139-44.

16. Almeida S.M., Queiroz-Telles, Teive H.A.G., et al. Central nervous system paracoccidioidomycosis: clinical features and laboratorial findings. Journal of Infection 2004;48:193-8.

17. Pereira W.C., Raphael A., Sallum J. Lesões neurológicas na blastomicose sul-americana: estudo anatomopatológico de 14 casos. Arq Neuropsiq 1965;23:95-126.

18. Franco M., Montenegro M.R., Mendes R.P., et al. Paracoccidioidomycosis: a recently proposed classification of its clinical forms. Revista da Sociedade Brasileira de Medicina Tropical 1987;20:129-32.

19. Raphael A. Localização Nervosa da blastomicose sulamericana. Arquivos de Neuropsiquiatria 1966;24:69-90.

20. Araujo J.C., Werneck L.C., Cravo M.A. South American blastomycosis presenting as a posterior fossa tumor. Journal of Neurosurgery 1978;49:425-8.

21. Colli B.O., Assirati Jr. J.A., Machado H.R., et al. Intramedullary spinal cord paracoccidioidomycosis: report of two cases. Arquivos de Neuropsiquiatria 1996;54:466-73.

22. Marchiori E., Freitas M.A.L., Lima R.A.M. Paracoccidioidomicose medular: relato de um caso. Arquivos de Neuropsiquiatria 1989;47:224-9.

23. Minguetti G., Madalozzo L.E. Paracoccidioidal granulomatosis ot the brain. Archives of Neurology 1983;40:100-2.

24. Pacheco R.A.B., Arruda W.O., Hunhevicz S.C., et al. Thoracic intraspinal paracoccidioidomycosis. Arquivos de Neuropsiquiatria 1996;54:474-8.

25. Teive H.A., Arruda W.O., Ramina R., et al. Paracoccidioidomycosis granuloma simulating posterior fossa tumor. Journal of the Royal Society of Medicine 1991;84:562-3. 
26. Wittig E.O., Kasting G., Leal R. Neuroblastomycosis: report of three cases. Arquivos de Neuropsiquiatria 1968;26:73-9.

27. Sano A., Miyaji M., Nishimura K. Studies on the relationship between paracoccidioidomycosis in ddY mice and their estrous cycle. Mycopathologia 1991; 115:73-81.

28. Pinto P.J., Silva A.Q., Silveira O. Blastomicose cerebral: forma isolada com sintomatologia de tumor cerebral. Revista Medica do Paraná 1959;28:57-62.

29. Teive H.A.G., Zanatta A., Germiniani F.M.B., et al. Holmes'tremor and neuroparacoccidioidomycosis: a case report. Movement Disorders 2002;17:1392-4.

30. Da Silva C.E., Cordeiro A.F., Gollner A.M., et al. Paracoccidioidomycosis of the central nervous system: case report. Arquivos de Neuropsiquiatria 2000;58:741-7.

31. Lambertucci J.R., Lana-Peixoto M.A., Pitella E.H. Paracoccidioidomycosis of the central nervous system. Revista da Sociedade Brasileira de Medicina Tropical 2001;34:395-6.

32. Lorenzoni P.J., Chang M.R., Paniago A.M.M., Salgado P.R. Meningite paracoccidioidomicotica: relato de caso. Arquivos de Neuropsiquiatria 2002;60:1015-8.

33. Canelas H.M., Lima F.P., Bittencourt I.M., et al. Blastomicose do sistema nervoso. Arquivos de Neuropsiquiatria 1951;9:203-22.

34. Braga F.M., Okamura M. Blastomicose medular. Seara Medica Neurocirurgica (São Paulo) 1973;1:435-41.

35. Farage M. Filho, Braga M.R.G., Kuhn M.D.S. Granuloma blastomicótico na medula cervical: registro de um caso. Arquivos de Neuropsiquiatria 1977;35:151-5.

36. Morato-Fernandez R.N., Beraldo P.S.S., Masini M., Costa P.H.C. Paracoccidioidomicose do sistema nervoso de localização intramedular e cerebral. Arquivos de Neuropsiquiatria 1991;49:192-7.

37. Moura L.P., Raffin C.N., Del Negro G.M.B., Ferreira M.S. Paracoccidioidomicose evidenciando comprometimento medular tratada com sucesso por fluconazol. Arquivos de Neuropsiquiatria 1994;52: 82-6.

38. Cano L.E., Restrepo A. Predictive value of serologic tests in the diagnosis and follow-up of patients with paracoccidioidomycosis. Revista do Instituto de Medicina Tropical de São Paulo 1987;29:276-83.

39. Del Negro G..M.B., Garcia N.M., Rodrigues E.G., et al. The sensitivity, specificity and efficiency values of some serological tests used in the diagnosis of paracoccidioidomycosis. Revista do Instituto de Medicina Tropical de São Paulo 1991;33:277-80.

40. Salina M.A., Shikanai-Yasuda M.A., Mendes R.P., et al. Detection of circulating Paracoccidioides brasiliensis antigen in urine of paracoccidioidomycosis patients before and during treatment. Journal of Clinical Microbiology 1998;36:1723-8.
41. Almeida S.M., Queiroz-Telles F., Doi E.M., et al. Anti-gp43 antibodies in the cerebrospinal fluid of patients with central nervous system involvement by paracoccidioidomycosis. American Journal of Clinical Pathology 2002; 118:864-8.

42. Schuller E., Duclos H. Liquide céphalo-rachidien normal et pathologique. In Encyclopidie Médico-Chirurgicale. Systéme nerveux. Paris 1976:1-14.

43. Sandhu G.S., Aleff R.A., Kline B.C., Lacaz C.S. Molecular detection and identification of Paracoccidioides brasiliensis. Journal of Clinical Microbiology 1997;35:1894-6.

44. Silva S.H.M., Colombo A.L., Blotta M.H.S.L., et al. Detection of circulating gp43 antigen in serum, cerebrospinal fluid, and bronchoalveolar lavage fluid of patients with paracoccidioidomycosis. Journal of Clinical Microbiology 2003;41:3675-80.

45. Camargo Z.P., Guesdon J.L., Drouhet E., Improvisi L. Titration of antibodies to Paracoccidioides brasiliensis by erythro-immunoassay (EIA). Journal of Medical and Veterinary Mycology 1984;22:73-7.

46. Camargo Z.P., Guesdon J.L., Drouhet E., Improvisi L. Enzyme linked immunosorbent assay (ELISA) in paracoccidioidomycosis. Mycopathologia 1984; $88: 31-7$.

47. Camargo Z.P., Unterkircher C., Travassos L.R. Identification of antigenic polypeptides of Paracoccidioides brasiliensis by immunoblotting. Journal of Medical and Veterinary Mycology 1989;27:407-12.

48. Camargo Z.P., Taborda C.P., Rodrigues E.G., Travassos L.R. The use of cell-free antigens of Pracoccidioides brasiliensis in serological tests. Journal of Medical and Veterinary Mycology 1991;29:31-8.

49. Puccia R., Schenkman S., Gorin A.J.P., Travassos L.R. Exocellular components of Paracoccidiodes brasiliensis: identification of a specific antigen. Infection and Immunity 1986;53:199-206.

50. Mendes-Giannini M.J., Bueno J.P., Shikanai-Yasuda M.A., et al. Detection of the 43,000-molecular-weight glycoprotein in sera of patients with paracoccidioidomycosis. Journal of Clinical Microbiology 1989;27:2842-5.

51. Mendes-Giannini M.J.S., Bueno J.P., Shikanai-Yasuda M.A., et al. Antibody response to the $43 \mathrm{kDa}$ glycoprotein of Paracoccidioides brasiliensis as a marker of evaluation of patients under treatment. American Journal of Tropical Medicine and Hygiene 1990;43:200-6.

52. Mendes-Giannini M.J.S., Toscano E., Del Negro G.B., et al. Immunochemical study of a Paracoccidioides brasiliensis polysaccharide-like antigen. Journal of Medical and Veterinary Mycology 1995;33:379-83. 
53. Puccia R., Travassos L.R. 43-kilodalton glycoprotein from Paracoccidioides brasiliensis: immunochemicalreactions with sera from patients with paracoccidioidomycosis, histoplasmosis or Jorge Lobo disease. Journal of Clinical Microbiology 1991;29:1610-5.

54. Bueno J.P., Mendes-Giannini M.J.S., Del Negro G.M.B., et al. Estudo do valor diagnostico da técnica ELISA anti-gp43 e da reação de imunofluorescência indireta anti-P. brasiliensis pesquisando-se anticorpos das classes IgG, IgM, IgA. Revista Argentina de Micologia 1992; $15: 54-8$.

55. Magalhães A.C.A., Bacheschi L.A., Caramelli P., et al. Paracoccidioidomicose do Sistema Nervoso Central: estudo de cinco casos por ressonância magnética. Revista do Hospital de Clinicas da Faculdade de Medicina de São Paulo 1993;48:94-7.

56. Minguetti G. Tomografia computadorizada dos granulomas blastomicóticos encefálicos. Revista do Instituto de Medicina Tropical de São Paulo 1983;25:99-107.

57. Rodacki M.A., De Toni G., Borba L.A., Oliveira G.G. Paracoccidioidomycosis of the central nervous system: CT findings. Neuroradiology 1995;37:636-41.

58. Gasparetto E.L., Liu C.B., Carvalho Neto A., Rogacheski E. Central Nervous System Paracoccidioidomycosis: imaging findings in 17 cases. Journal of Computer Assisted Tomography 2003;27:12-7.

59. Villa L.A., Tobon A., Restrepo A., et al. Central nervous system paracoccidioidomycosis. Report of a case successfully treated with itraconazol. Revista do Instituto de Medicina Tropical de Sao Paulo 2000; $42: 231-4$.

60. Kappe R. Antifungal activity of the new azole UK-109 (voriconazole). Mycoses 1999;42(suppl 2):83-6.

61. Pedro R.J., Aoki F.H., Boccato R.S., et al. Paracoccidioidomycosis and infection by the human immunodeficiency virus. Revista do Instituto de Medicina Tropical de São Paulo 1989;31:119-25.

62. Almeida S.M., Rebelatto C.L.K., Queiroz-Telles F., Werneck L.C. Major histocompatibility complex and central nervous system involvement by paracoccidioidomycosis. Journal of Infection 2004 (accepted, in press).

63. Restrepo F.M., Restrepo M., Restrepo A. Blood groups and HLA antigens in paracoccidioidomycosis. Journal of Medical and Veterinary Mycology 1983;21:35-9.

64. González N.M., Albornoz M.B., Ríos R., Prado L. HLA y paracoccidioidomycosis. Cien Tecnol Venez 1985;2:229-34.

65. Lacerda G.B., Arce-Gomez B., Telles Filho F.Q. Increased frequency of HLA-B40 in patients with paracoccidioidomycosis. Journal of Medical and Veterinary Mycolog y 1988;26:253-6.
66. Goldani L.Z., Monteiro C.M.C., Donadi E.A., et al. HLA antigens in Brazilian patients with paracoccidioidomycosis. Mycopathologia 1991;114:89-91.

67. Visentainer J.E.L., Tsuneto L.T., Moliterno R.A., Telles Filho F.Q. Lack of association between paracoccidioidomycosis and HLA histocompatibility antigens. Revista Brasileira de Genetica 1993; 16 :1035-41.

68. Probst C.M., Bompeixe E.P., Pereira N.F., et al. HLA polymorphism and evaluation of european, african and amerindian contribution to the white and mulatto populations from Paraná, Brazil. Human Biology 2000;72:597-617. 